Article

\title{
Antimicrobial Activity of Extracts of Two Native Fruits of Chile: Arrayan (Luma apiculata) and Peumo (Cryptocarya alba)
}

\author{
Jitka Viktorová ${ }^{1}$, Rohitesh Kumar ${ }^{1}$, Kateřina Řehořová ${ }^{1}$, Lan Hoang ${ }^{1}{ }^{1}$, Tomas Ruml ${ }^{1}{ }^{1}$, \\ Carlos R. Figueroa ${ }^{2}$ (D), Monika Valdenegro ${ }^{3}(\mathbb{D})$ and Lida Fuentes $4, * \mathbb{D}$ \\ 1 Department of Biochemistry and Microbiology, University of Chemistry and Technology Prague, \\ 16628 Prague, Czech Republic; Jitka.Prokesova@vscht.cz (J.V.); Rohitesh.Kumar@vscht.cz (R.K.); \\ Katerina.Rehorova@vscht.cz (K.ॅ̌.); Lan.Hoang@vscht.cz (L.H.); tomas.ruml@vscht.cz (T.R.) \\ 2 Institute of Biological Sciences, Campus Talca, Universidad de Talca, Talca 3465548, Chile; cfigueroa@utalca.cl \\ 3 Agronomy School, Faculty of Agronomic and Food Sciences, Pontificia Universidad Católica de Valparaíso, \\ Quillota 2260000, Chile; monika.valdenegro@pucv.cl \\ 4 Regional Center for Studies in Healthy Food (CREAS), CONICYT-Regional GORE Valparaíso Project \\ R17A10001, Avenida Universidad, Valparaíso 2340000, Chile \\ * Correspondence: lfuentes@creas.cl
}

Received: 22 June 2020; Accepted: 21 July 2020; Published: 25 July 2020

\begin{abstract}
Arrayan and peumo fruits are commonly used in the traditional medicine of Chile. In this study, the concentration of the extracts halving the bacterial viability and biofilms formation and disruption of the drug-sensitive and drug-resistant strains of Staphylococcus aureus and Pseudomonas aeruginosa was determined. The chemical composition of extracts was analyzed by high-resolution liquid chromatography coupled with mass spectrometry (U-HPLC/MS). The arrayan extract (Inhibitory concentration $\left.\mathrm{IC}_{50} 0.35 \pm 0.01 \mathrm{mg} / \mathrm{mL}\right)$ was more effective than peumo extract $\left(\mathrm{IC}_{50} 0.53 \pm 0.02 \mathrm{mg} / \mathrm{mL}\right)$ in the inhibition of $S$. aureus planktonic cells. Similarly, the arrayan extract was more effective in inhibiting the adhesion (S. aureus $\mathrm{IC}_{50} 0.23 \pm 0.02 \mathrm{mg} / \mathrm{mL}$, P. aeruginosa $\mathrm{IC}_{50} 0.29 \pm 0.02 \mathrm{mg} / \mathrm{mL}$ ) than peumo extracts (S. aureus $\mathrm{IC}_{50} 0.47 \pm 0.03 \mathrm{mg} / \mathrm{mL}$, P. aeruginosa $\mathrm{IC}_{50} 0.35 \pm 0.01 \mathrm{mg} / \mathrm{mL}$ ). Both extracts inhibited quorum sensing in a concentration-dependent manner, and the most significant was the autoinducer-2 type communication inhibition by arrayan extract. Both extracts also disrupted preformed biofilm of $P$. aeruginosa (arrayan $\mathrm{IC}_{50} 0.56 \pm 0.04 \mathrm{mg} / \mathrm{mL}$, peumo $\mathrm{IC}_{50} 0.59 \pm 0.04 \mathrm{mg} / \mathrm{mL}$ ). However, neither arrayan nor peumo extracts disrupted S. aureus mature biofilm. U-HPLC/MS showed that both fruit extracts mainly possessed quercetin compounds; the peumo fruit extract also contained phenolic acids and phenylpropanoids. Our results suggested that both extracts could be used as natural antimicrobials for some skin and nosocomial infections.
\end{abstract}

Keywords: traditional medicine; drug-resistant bacteria; high-resolution HPLC/MS; biofilm disruption; quorum sensing

\section{Introduction}

As part of the diets, many fruits of native species have been used as a traditional medicine in the South American region [1,2]. The Chilean trees, arrayan [Luma apiculata (DC.) Burret] and peumo [Cryptocarya alba (Molina) Looser], are ancestral species used in food and medicinal preparations [3,4]; however, the antimicrobial properties of both species are have not yet been described in detail.

Arrayan (Luma apiculata) is a Myrtaceae [5] endemic plant from the Valparaiso to Aysen regions of Chile (latitude $33^{\circ}$ to $45^{\circ} \mathrm{S}$ ). It grows in the temperate forests of Chile and Argentina. Its fruit is an edible black or purple berry (Figure 1A), with an intense flavor, aromatic, and a pleasant sweet 
taste. Luma species (namely L. apiculata and L. chequen) have been previously described as a rich source of phenolic compounds with high antioxidant activity [4]. Extracts of ripe fruits of arrayan showed the presence of flavonol and anthocyanins, with high oxygen radical absorption capacity and concentration-dependent vascular protection under high glucose conditions [6]. Moreover, aqueous extracts demonstrated inhibition of the collagen-induced aggregation of platelets in human blood [7], indicating the potency to treat wounds and inflammations. Further, the addition of dry leaves into the lettuce substratum resulted in better control of Meloidogyne hapla population, nematode known as a vegetable pathogen, which produces tiny galls [8]. Arrayan has also shown activity against Herpes simplex virus type 2 [9].
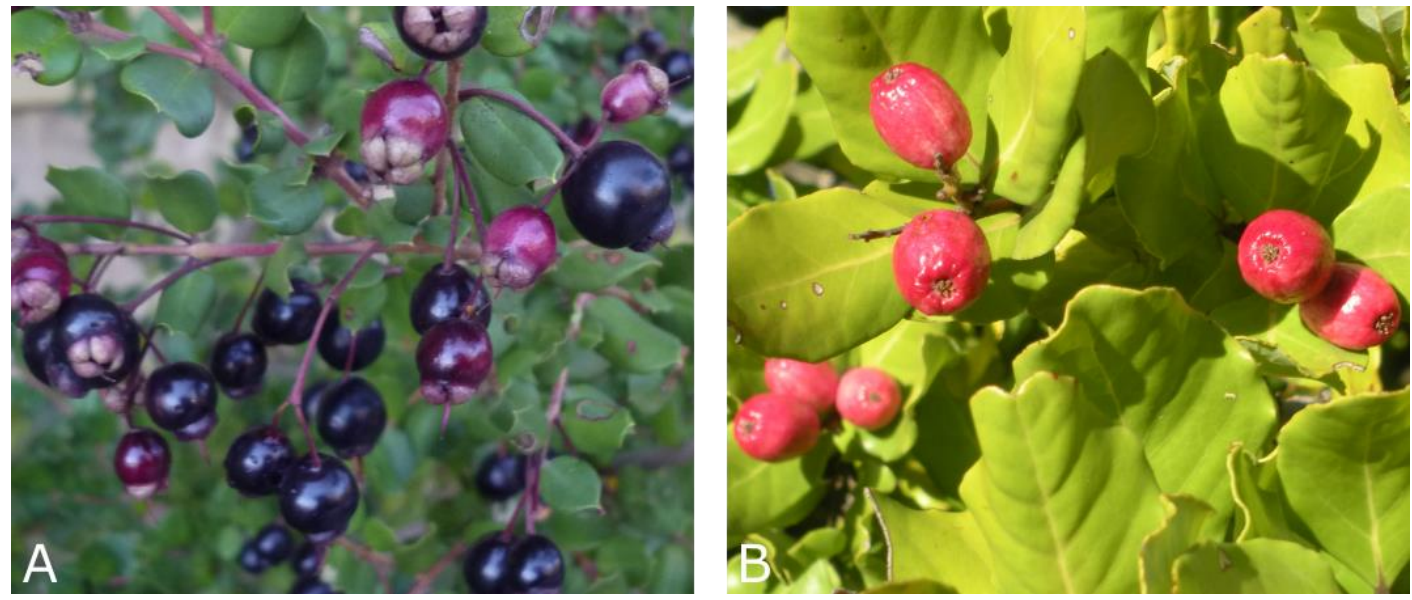

Figure 1. Branches with leaves and fruits of arrayan and peumo. (A) Arrayan [Luma apiculata (DC.) Burret.] *; (B) Peumo [Cryptocarya alba (Molina) Looser] **. Photography credit to Carlos R. Figueroa ${ }^{*}$ ) and Lida Fuentes $(* *)$.

Peumo belongs to the Lauraceae family and is spread from the Maule to Araucania regions of Chile (latitude $35^{\circ}$ to $38^{\circ} \mathrm{S}$ ). The ripe fruit is a red to smooth pink berry (Figure 1B), crowned with the remains of the stamens and calyx lobes. It has a large seed similar to a nut. Its leaves and bark are used in traditional medicine to treat liver diseases and rheumatism [10]. The essential oil prepared by the distillation of peumo showed activity against Nosema ceranae, the originator of nosemosis in honeybee [11]; against insect Sitophilus zeamais Motschulsky, known as a maize weevil, causing significant loses during cereals' storage [12]; and against Musca domestica L. [13]. Moreover, the leaves extract demonstrated a protective effect against ethyl methane sulphonate-induced mutagenesis in Drosophila melanogaster [14]. The edible peumo skin has a large number of polyphenolic compounds [15], related to high antioxidant capacity $[15,16]$. Besides the other biologically active compounds, cryptofolione and its dihydro-derivative were isolated from the fruits of C. alba [17]. In the trypanocidal assay, cryptofolione at $250 \mu \mathrm{g} / \mathrm{mL}$ reduced the number of trypomastigotes by $77 \%$, while its dihydro-derivative was inactive. However, cryptofolione at tenfold lower concentration $(25 \mu \mathrm{g} / \mathrm{mL})$ reduced the viability of macrophages, demonstrating a cytotoxic effect instead of selectivity towards Trypanosoma cruzi [17].

The antimicrobial activity of fruit extracts, including the native fruits of Chile, has usually been related to total phenolic content and compounds such as chlorogenic acid, quercetin, ellagic acid, and quercetin-3-galactoside [18-21]. The hydroxyl groups of polyphenolic compounds play a significant role in inhibiting the key enzymatic activities of bacteria and inducing cell toxicity [22].

This study aimed to characterize the antimicrobial activity and the phytochemical profile of fruit-extracts and seek potential uses of arrayan and peumo species in the medicinal treatment. 


\section{Results}

\subsection{Inhibition of Multidrug-Resistant Bacterial Strains}

As drug-resistant strains, we used clinical isolates obtained from the Collection of the Laboratory of Medical Microbiology (Czech Laboratory, lnc., NEM) resistant to several drugs. Overall, arrayan extract was effective in inhibiting both the drug-resistant and drug-sensitive strains of S. aureus, with almost the same $\mathrm{IC}_{50}$ values (Table 1 ). However, the extract showed activity against neither the drug-sensitive nor the drug-resistant strains of $P$. aeruginosa up to the concentration of $1 \mathrm{mg} / \mathrm{mL}$. In lower concentrations, the beneficial (growth-promoting) effect of the extract was observed. Peumo extract was slightly less effective and did not show any specificity towards the $S$. aureus strains. However, unlike arrayan, the peumo extract exhibited weak activity against the drug-resistant strain of $P$. aeruginosa with the $\mathrm{IC}_{50}$ value of $0.778 \pm 0.004 \mathrm{mg} / \mathrm{mL}$.

Table 1. Inhibition of multidrug-resistant bacterial strains. Commercial antibiotics oxacillin or gentamicin served as the positive controls for S. aureus and P. aeruginosa, respectively.

\begin{tabular}{|c|c|c|c|c|}
\hline \multirow[b]{2}{*}{ Extract/Compound } & \multicolumn{4}{|c|}{$\mathrm{IC}_{50}(\mathrm{mg} / \mathrm{mL})$} \\
\hline & $\begin{array}{c}\text { S. aureus } \\
\text { (ATCC 25923) } \\
\text { sensitive strain }\end{array}$ & $\begin{array}{c}\text { S. aureus } \\
\text { (NEM 449) } \\
\text { resistant strain * }\end{array}$ & $\begin{array}{c}\text { P. aeruginosa } \\
\text { (ATCC 27853) } \\
\text { sensitive strain }\end{array}$ & $\begin{array}{l}\text { P. aeruginosa } \\
\text { (NEM 986) } \\
\text { resistant strain ** }\end{array}$ \\
\hline Peumo & $0.533 \pm 0.018^{c}$ & $0.557 \pm 0.034^{c}$ & $>1$ & $0.778 \pm 0.004^{b}$ \\
\hline Arrayan & $0.354 \pm 0.007^{\mathrm{b}}$ & $0.385 \pm 0.013^{b}$ & $>1$ & $>1$ \\
\hline Antibiotics & $0.0046 \pm 0.0002^{a}$ & $0.040 \pm 0.002^{\mathrm{a}}$ & $0.0002 \pm 0.000$ & $>0.150^{\mathrm{a}}$ \\
\hline
\end{tabular}

Data represent the average of four repetitions with corresponding standard errors of the mean. The data were analyzed with analysis of variance (ANOVA) $(p<0.05)$ and the statistical significances within one bacterial strain were denoted by different letters $(\mathrm{a}, \mathrm{b}, \mathrm{c}) .{ }^{*}$ Resistant to gentamicin, clindamycin, erythromycin, chloramphenicol, vancomycin, ciprofloxacin, methicillin, penicillin G, cefotaxime, and tetracycline. ** Resistant to gentamycin, ciprofloxacin, tetracycline, chloramphenicol, penicillin $\mathrm{G}$, and erythromycin.

As shown in Table 1, both extracts showed reasonable direct toxicity against drug-resistant strains (higher against the Gram-positive $S$. aureus); therefore, their ability to modulate the drug-resistant phenotype was also tested. Both extracts were applied in a dose equal to $\mathrm{IC}_{25}$ concentration obtained for drug-resistant S. aureus $(240 \mu \mathrm{g} / \mathrm{mL}$ for peumo and $270 \mu \mathrm{g} / \mathrm{mL}$ for arrayan) on both drug-resistant strains $S$. aureus and P. aeruginosa). After that, $\mathrm{IC}_{50}$ of chloramphenicol in the presence of the extracts was determined and compared with $\mathrm{IC}_{50}$ of the antibiotic alone. However, the addition of neither arrayan nor peumo extract decreased the $\mathrm{IC}_{50}$ of chloramphenicol (Table 2). Thus, even that both extracts inhibited the drug-resistant strains, their mode of action was instead direct cytotoxicity than selective modulation of drug resistance.

Table 2. Modulation of the drug-resistant phenotype in bacteria by arrayan and peumo extract. The fold is expressed as a ratio of $\mathrm{IC}_{50}$ of antibiotics and $\mathrm{IC}_{50}$ of antibiotics with the addition of extract at $\mathrm{IC}_{25}$ concentration.

\begin{tabular}{ccc}
\hline Sample & \multicolumn{2}{c}{ Fold } \\
\hline & S. aureus & P. aeruginosa \\
Extract & (NEM 449) & (NEM 986) \\
& resistant strain & resistant strain \\
Peumo & $0.388 \pm 0.0002$ & $0.547 \pm 0.0003$ \\
Arrayán & $0.865 \pm 0.0006$ & $0.485 \pm 0.0007$ \\
\hline
\end{tabular}

$0.5<$ FOLD $>1$ indifferent effect, $0.5>$ FOLD antagonistic effect, $1<$ FOLD $>2$ additive effect, $2<$ FOLD synergistic effect.

\subsection{Inhibition of Biofilm Formation}

To test the inhibition of biofilm formation, the ability of extracts to inhibit cell adhesion of drug-sensitive strains was determined. Overall, compared with the peumo extract, the arrayan extract 
was slightly more active against both $S$. aureus and $P$. aeruginosa strains. The arrayan extract was more effective towards $S$. aureus strain (Table 3).

Table 3. Inhibition of biofilm formation.

\begin{tabular}{ccc}
\hline Sample & \multicolumn{2}{c}{ IC $_{50}(\mathbf{m g} / \mathbf{m L})$} \\
\hline Extract & S. aureus & P. aeruginosa \\
& $($ ATCC 25923) & (ATCC 27853) \\
Peumo & $0.473 \pm 0.028^{\mathrm{b}}$ & $0.346 \pm 0.013^{\mathrm{b}}$ \\
Arrayan & $0.229 \pm 0.017^{\mathrm{a}}$ & $0.288 \pm 0.021^{\mathrm{a}}$ \\
\hline
\end{tabular}

Data represent the average of 16 repetitions with corresponding standard errors of the mean. The data were analyzed with ANOVA $(p<0.05)$ and the statistical significances within one bacterial strain were denoted by different letters $\left({ }^{a}, b\right)$.

\subsection{Disruption of Mature Biofilm}

Both arrayan and peumo extracts did not disrupt mature biofilm of S. aureus (Table 4), contrary to the results observed for both extracts on the mature biofilm of P. aeruginosa.

Table 4. Disruption of mature biofilm.

\begin{tabular}{ccc}
\hline Sample & \multicolumn{2}{c}{ IC $_{\mathbf{5 0}}(\mathbf{m g} / \mathbf{m L})$} \\
\hline \multirow{2}{*}{ Extract } & S. aureus & P. aeruginosa \\
Peumo & (ATCC 25923) & (ATCC 27853) \\
Arrayan & No activity & $0.586 \pm 0.042^{\mathrm{a}}$ \\
& No activity & $0.559 \pm 0.040^{\mathrm{a}}$ \\
\hline
\end{tabular}

Data represent the average of 16 repetitions with corresponding standard errors of the mean. The data were analyzed with ANOVA $(p<0.05)$ and the statistical significances within one bacterial strain were denoted by different letters.

\subsection{Inhibition of Quorum Sensing}

The inhibition of bacterial adhesion is usually connected with the inhibition of bacterial extracellular communication. To verify the anti-adhesion results, inhibition of quorum sensing was tested using two mutant sensor strains of Vibrio campbellii, which responds either only to (i) autoinducer type-1 (AI-1) molecules (BAA1118) or (ii) autoinducer type-2 (AI-2) molecules (BAA1119). As can be seen in Table 5, the concentrations halving the viability differed significantly from those halving the communication. The decrease in luminescence was thus caused by inhibition of communication rather than inhibition of cell growth. The peumo extract was more effective in inhibiting AI-1 based communication, which is more typical for Gram-negative bacteria. In contrast, the AI-2 type communication was inhibited rather by the arrayan extract. As the AI-2 type communication is based on boron compounds and is used by both Gram-positive and Gram-negative bacteria, the inhibition caused by arrayan extract is more promising.

Table 5. Inhibition of quorum sensing.

\begin{tabular}{ccccc}
\hline Sample & \multicolumn{4}{c}{$\mathrm{IC}_{\mathbf{5 0}}(\mu \mathrm{g} / \mathrm{mL})$} \\
\hline \multirow{2}{*}{ Extract } & AI-1 strain BAA $1118(\mathrm{G}-)$ & AI-2 strain BAA $1119(\mathrm{G}+, \mathrm{G}-)$ \\
& viability & communication & viability & communication \\
Peumo & $165.7 \pm 21.8^{\mathrm{a}}$ & $25.6 \pm 0.3^{\mathrm{a}}$ & $147.4 \pm 2.3^{\mathrm{a}}$ & $96.2 \pm 7.4^{\mathrm{b}}$ \\
Arrayan & $447.7 \pm 71.6^{\mathrm{b}}$ & $127.2 \pm 5.9^{\mathrm{b}}$ & $111.5 \pm 15.3^{\mathrm{a}}$ & $39.9 \pm 3.9^{\mathrm{a}}$ \\
\hline
\end{tabular}

Data represent the average of three repetitions with corresponding standard errors of the mean. The data were analyzed with ANOVA $(p<0.05)$ and statistical significances within one bacterial strain were denoted by different letters $\left({ }^{a, b}\right)$. 
2.5. High-Resolution Liquid Chromatography Coupled with Mass Spectrometry (U-HPLC/MS) of Arrayan and Peumo Extracts

U-HPLC/MS analysis showed that arrayan samples are rich in polyphenolics such as catechins, quercetins, and myricetins (Figure 2, Table 6). Peumo samples are rich in polyphenolics such as procyanidins, chlorogenic acid and its analogous, catechins, and quercetins. Moreover, this extract shows the presence of (+)-lariciresinol, a phenylpropanoid compound (Figure 3, Table 7). In the extracts of both fruits tested, there were some molecular ions and molecular formula that did not reveal any hits from the SciFinder database in the search using the molecular mass and the sample names. This indicates that these compounds have not yet been reported to occur in these plant species. Therefore, these are labelled as unidentified in the tables.

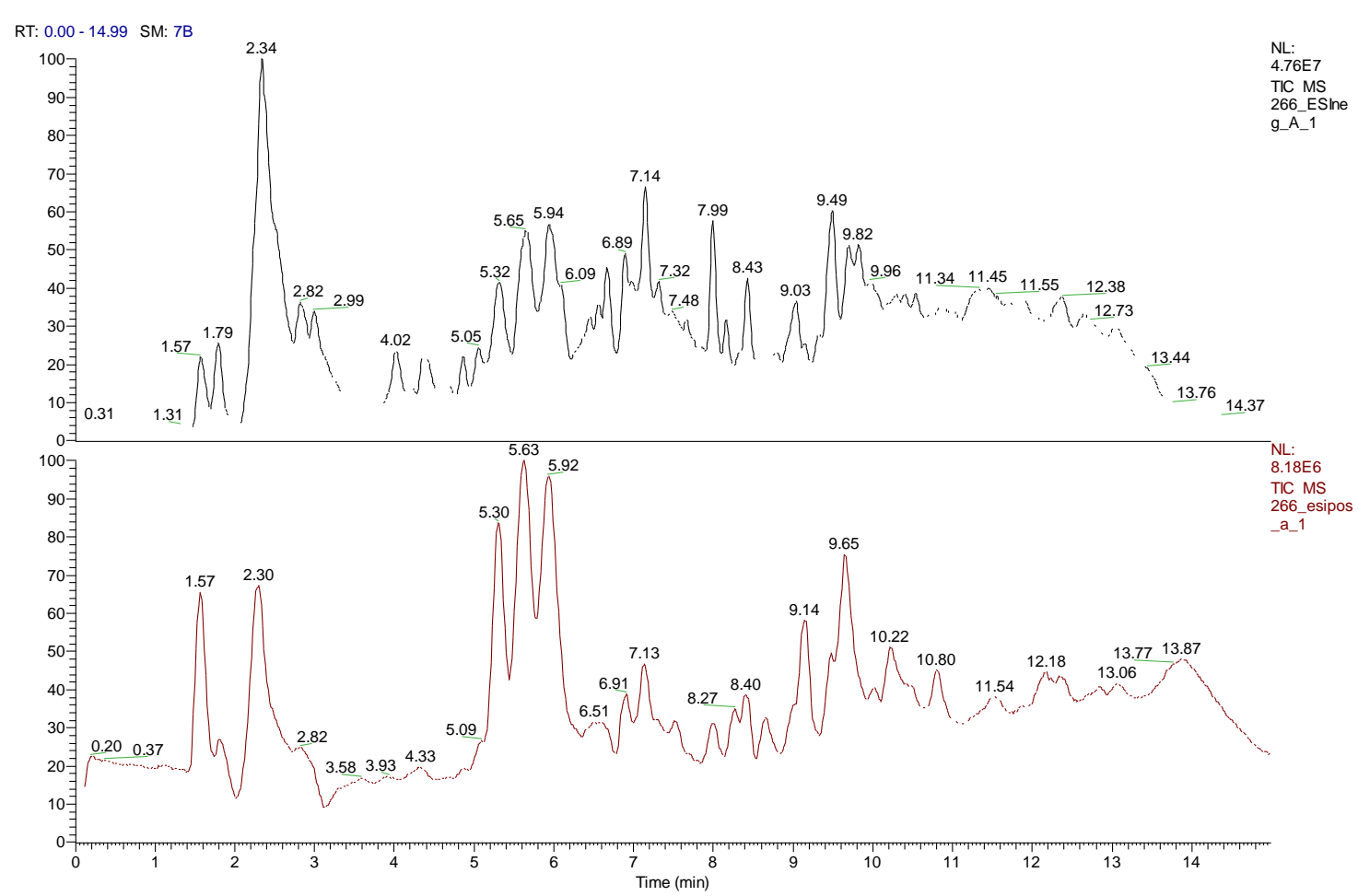

Figure 2. Total ion chromatogram (TIC) for arrayan. TIC of arrayan extract is shown in negative and positive modes.

Table 6. Identification of compounds from arrayan fruits by liquid chromatography coupled with mass spectrometry (LC-MS) and MS/MS data. The principal peaks were individually analyzed, and the potential compounds were analyzed. RT, retention time; MF, molecular formula.

\begin{tabular}{|c|c|c|c|c|c|c|}
\hline RT (min) & $\begin{array}{c}{[\mathrm{M}+\mathrm{X}]^{+}} \\
(\mathrm{m} / \mathrm{z})\end{array}$ & $\begin{array}{c}{[\mathrm{M}-\mathrm{X}]^{-}} \\
(\mathrm{m} / \mathrm{z})\end{array}$ & $\begin{array}{c}{[\mathrm{M}]} \\
(\mathrm{m} / \mathrm{z})\end{array}$ & Fragments & MF & Tentative Compound \\
\hline \multirow[t]{2}{*}{4.02} & - & $\begin{array}{l}466.0311 \\
{[\mathrm{M}-\mathrm{H}]^{-}}\end{array}$ & 467 & $169.0149,211.0259,271.0476$ & $\mathrm{C}_{26} \mathrm{H}_{10} \mathrm{O}_{9}$ & Unidentified \\
\hline & - & 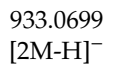 & & & & \\
\hline \multirow[t]{2}{*}{4.35} & - & $\begin{array}{l}466.0311 \\
{[\mathrm{M}-\mathrm{H}]^{-}}\end{array}$ & 467 & $156.1025,184.0957$ & $\mathrm{C}_{26} \mathrm{H}_{10} \mathrm{O}_{9}$ & Unidentified \\
\hline & $\begin{array}{c}935.0790 \\
{[2 \mathrm{M}+\mathrm{H}]^{+}}\end{array}$ & $\begin{array}{l}933.0699 \\
{[2 \mathrm{M}-\mathrm{H}]^{-}}\end{array}$ & & & & \\
\hline 5.05 & $\begin{array}{l}307.0813 \\
{[\mathrm{M}+\mathrm{H}]^{+}}\end{array}$ & $\begin{array}{l}305.0685 \\
{[\mathrm{M}-\mathrm{H}]^{-}}\end{array}$ & 306 & $\begin{array}{c}125.0247,137.0248,151.0406, \\
167.0356,179.0358,219.0675, \\
221.0467\end{array}$ & $\mathrm{C}_{15} \mathrm{H}_{14} \mathrm{O}_{7}$ & $\begin{array}{l}\text { Epigallocatechin } \\
\text { Gallocatechin }\end{array}$ \\
\hline
\end{tabular}


Table 6. Cont.

\begin{tabular}{|c|c|c|c|c|c|c|}
\hline RT (min) & $\begin{array}{c}{[\mathrm{M}+\mathrm{X}]^{+}} \\
(\mathrm{m} / \mathrm{z})\end{array}$ & $\begin{array}{c}{[\mathrm{M}-\mathrm{X}]^{-}} \\
(\mathrm{m} / \mathbf{z})\end{array}$ & $\begin{array}{c}{[\mathrm{M}]} \\
(\mathrm{m} / \mathrm{z})\end{array}$ & Fragments & MF & Tentative Compound \\
\hline 5.29 & $\begin{array}{l}465.1029 \\
{[\mathrm{M}+\mathrm{H}]^{+}}\end{array}$ & $\begin{array}{l}463.0915 \\
{[\mathrm{M}-\mathrm{H}]^{-}}\end{array}$ & 464 & $-301.0375,337.0589$ & $\mathrm{C}_{21} \mathrm{H}_{20} \mathrm{O}_{12}$ & $\begin{array}{c}\text { Quercetin } \\
\text { 3-glucosideMyricetin } \\
\text { Hyperoside } \\
\text { Isoquercetrin }\end{array}$ \\
\hline \multirow[t]{2}{*}{5.63} & $\begin{array}{l}479.1188 \\
{[\mathrm{M}+\mathrm{H}]^{+}}\end{array}$ & $\begin{array}{l}477.1071 \\
{[\mathrm{M}-\mathrm{H}]^{-}}\end{array}$ & 478 & -315.0533 & $\mathrm{C}_{22} \mathrm{H}_{22} \mathrm{O}_{12}$ & $\begin{array}{l}\text { Isohamnetin-3-O- } \beta \\
\text {-D-galactoside }\end{array}$ \\
\hline & $\begin{array}{l}449.1083 \\
{[\mathrm{M}+\mathrm{H}]^{+}}\end{array}$ & $\begin{array}{l}447.0964 \\
{[\mathrm{M}-\mathrm{H}]^{-}}\end{array}$ & 448 & & $\mathrm{C}_{21} \mathrm{H}_{20} \mathrm{O}_{11}$ & $\begin{array}{c}\text { Quercitrin } \\
\text { Isoorientin } \\
\text { Luteolin 7-O-glucoside }\end{array}$ \\
\hline 5.92 & $\begin{array}{l}493.1346 \\
{[\mathrm{M}+\mathrm{H}]^{+}}\end{array}$ & $\begin{array}{l}491.1230 \\
{[\mathrm{M}-\mathrm{H}]^{-}}\end{array}$ & 492 & $-169.0150,305.0678,331.0481$ & $\mathrm{C}_{23} \mathrm{H}_{24} \mathrm{O}_{12}$ & Unidentified \\
\hline 6.88 & $\begin{array}{l}481.0974 \\
{[\mathrm{M}+\mathrm{H}]^{+}}\end{array}$ & $\begin{array}{l}479.0858 \\
{[\mathrm{M}-\mathrm{H}]^{-}}\end{array}$ & 480 & $\begin{array}{c}+245.0453,263.0559,273.0403 \\
319.0449\end{array}$ & $\mathrm{C}_{21} \mathrm{H}_{20} \mathrm{O}_{13}$ & $\begin{array}{l}\text { Myricetin } \\
\text { 3-O-galactoside }\end{array}$ \\
\hline 7.14 & $\begin{array}{l}465.1027 \\
{[\mathrm{M}+\mathrm{H}]^{+}}\end{array}$ & $\begin{array}{l}463.0912 \\
{[\mathrm{M}-\mathrm{H}]^{-}}\end{array}$ & 464 & & $\mathrm{C}_{21} \mathrm{H}_{20} \mathrm{O}_{12}$ & $\begin{array}{c}\text { myricitin } \\
\text { Quercetin 3-glucoside } \\
\text { Quercetin 3-O- } \beta \text {-D- } \\
\text { allopyranoside } \\
\text { Isoquercitrin } \\
\text { Hyperoside }\end{array}$ \\
\hline \multirow[t]{2}{*}{7.99} & $\begin{array}{l}599.2699 \\
{[\mathrm{M}+\mathrm{H}]^{+}}\end{array}$ & $\begin{array}{l}597.2589 \\
{[\mathrm{M}-\mathrm{H}]^{-}}\end{array}$ & 598 & $-271.0476,313.0585,485.1695$ & $\mathrm{C}_{29} \mathrm{H}_{42} \mathrm{O}_{13}$ & Unidentified \\
\hline & $\begin{array}{l}621.2517 \\
{[\mathrm{M}+\mathrm{Na}]^{+}}\end{array}$ & $\begin{array}{l}1195.5236 \\
{[2 \mathrm{M}-\mathrm{H}]^{-}}\end{array}$ & & & & \\
\hline \multirow[t]{2}{*}{9.14} & $\begin{array}{l}387.1803 \\
{[\mathrm{M}+\mathrm{H}]^{+}}\end{array}$ & - & 386 & 289.1053 & $\mathrm{C}_{22} \mathrm{H}_{27} \mathrm{O}_{6}$ & Unidentified \\
\hline & $\begin{array}{c}409.1621 \\
{[\mathrm{M}+\mathrm{Na}]^{+}}\end{array}$ & - & & & & \\
\hline 9.45 & $\begin{array}{l}225.1121 \\
{[\mathrm{M}+\mathrm{H}]^{+}} \\
\end{array}$ & $\begin{array}{l}223.0987 \\
{ }^{[\mathrm{M}-\mathrm{H}]^{-}}\end{array}$ & 224 & $\begin{array}{c}-179.1085 \\
+139.0395,155.0343,207.1024 \\
\end{array}$ & $\mathrm{C}_{12} \mathrm{H}_{16} \mathrm{O}_{4}$ & Unidentified \\
\hline \multirow[t]{2}{*}{9.51} & $\begin{array}{l}503.3371 \\
{[\mathrm{M}+\mathrm{H}]^{+}}\end{array}$ & $\begin{array}{l}501.3255 \\
{[\mathrm{M}-\mathrm{H}]^{-}}\end{array}$ & 502 & $\begin{array}{c}+139.0402,155.0352,165.0561 \\
207.1035\end{array}$ & $\mathrm{C}_{30} \mathrm{H}_{46} \mathrm{O}_{6}$ & $\begin{array}{c}\text { Guavenoic acid } \\
\text { Guavalanostenoic acid }\end{array}$ \\
\hline & $\begin{array}{c}525.3193 \\
{\left[^{\mathrm{M}+\mathrm{Na}]^{+}}\right.} \\
\end{array}$ & $\begin{array}{l}1003.6580 \\
{[2 \mathrm{M}-\mathrm{H}]^{-}}\end{array}$ & & & & \\
\hline \multirow[t]{3}{*}{9.63} & $\begin{array}{l}415.2113 \\
{[\mathrm{M}+\mathrm{H}]^{+}}\end{array}$ & & 414 & +303.1211 & $\mathrm{C}_{24} \mathrm{H}_{30} \mathrm{O}_{6}$ & Unidentified \\
\hline & $\begin{array}{c}437.1931 \\
{[\mathrm{M}+\mathrm{Na}]^{+}}\end{array}$ & & & & & \\
\hline & $\begin{array}{c}851.3975 \\
{[2 \mathrm{M}+\mathrm{Na}]^{+}}\end{array}$ & & & & & \\
\hline
\end{tabular}

Table 7. Identification of compounds from peumo fruits by liquid chromatography coupled with mass spectrometry (LC-MS) and MS/MS data. The principal peaks were individually analyzed, and the potential compounds were analyzed. RT, retention time; MF, molecular formula.

\begin{tabular}{|c|c|c|c|c|c|c|}
\hline RT (min) & $\begin{array}{c}{[\mathrm{M}+\mathrm{X}]^{+}} \\
(\mathrm{m} / \mathrm{z})\end{array}$ & $\begin{array}{c}{[M-X]^{-}} \\
(\mathrm{m} / \mathrm{z})\end{array}$ & $\begin{array}{c}{[\mathrm{M}]} \\
(\mathrm{m} / \mathrm{z})\end{array}$ & Fragments & MF & Tentative Compound \\
\hline 2.37 & - & $\begin{array}{l}341.1032 \\
{[\mathrm{M}-\mathrm{H}]^{-}} \\
683.2142 \\
{[2 \mathrm{M}-\mathrm{H}]^{-}}\end{array}$ & 342 & $\begin{array}{l}-89.0227,101.0226 \\
119.0330,143.0329 \\
161.0433,179.0537\end{array}$ & $\mathrm{C}_{19} \mathrm{H}_{18} \mathrm{O}_{6}$ & Unidentified \\
\hline 5.23 & $\begin{array}{l}579.1509 \\
{[\mathrm{M}+\mathrm{H}]^{+}}\end{array}$ & $\begin{array}{l}577.1362 \\
{[\mathrm{M}-\mathrm{H}]^{-}} \\
599.1181 \\
{[\mathrm{M}-\mathrm{Na}]^{-}}\end{array}$ & 578 & $\begin{array}{c}-289.0743,407.0809 \\
425.0913,451.1071\end{array}$ & $\mathrm{C}_{30} \mathrm{H}_{26} \mathrm{O}_{12}$ & $\begin{array}{l}\text { Procyanidin } B_{1} \\
\text { Procyanidin } B_{2}\end{array}$ \\
\hline 6.11 & $\begin{array}{l}355.1033 \\
{[\mathrm{M}+\mathrm{H}]^{+}}\end{array}$ & $\begin{array}{l}353.0875 \\
{[\mathrm{M}-\mathrm{H}]^{-}} \\
707.1821 \\
{[2 \mathrm{M}-\mathrm{H}]^{-}}\end{array}$ & 354 & & $\mathrm{C}_{16} \mathrm{H}_{18} \mathrm{O}_{9}$ & $\begin{array}{c}\text { Chlorogenic acid } \\
\text { 4-Caffeoylquinic acid }\end{array}$ \\
\hline
\end{tabular}


Table 7. Cont.

\begin{tabular}{|c|c|c|c|c|c|c|}
\hline RT (min) & $\begin{array}{l}{[\mathrm{M}+\mathrm{X}]^{+}} \\
(\mathrm{m} / \mathrm{z})\end{array}$ & $\begin{array}{l}{[\mathrm{M}-\mathrm{X}]^{-}} \\
(\mathrm{m} / \mathrm{z})\end{array}$ & $\begin{array}{l}{[\mathrm{M}]} \\
(\mathrm{m} / \mathrm{z})\end{array}$ & Fragments & MF & Tentative Compound \\
\hline 6.24 & - & $\begin{array}{l}289.0718 \\
{[\mathrm{M}-\mathrm{H}]^{-}} \\
579.1511 \\
{[2 \mathrm{M}-\mathrm{H}]^{-}}\end{array}$ & 290 & $\begin{array}{c}-179.0357,205.0516 . \\
245.0811\end{array}$ & $\mathrm{C}_{15} \mathrm{H}_{14} \mathrm{O}_{6}$ & $\begin{array}{l}\text { Catechin, } \\
\text { Epicatechin }\end{array}$ \\
\hline 6.38 & $\begin{array}{c}470.1667 \\
{[\mathrm{M}+\mathrm{H}]^{+}} \\
492.1486 \\
{[\mathrm{M}+\mathrm{Na}]^{+}}\end{array}$ & $\begin{array}{l}468.1505 \\
{[\mathrm{M}-\mathrm{H}]^{-}} \\
937.3083 \\
{[2 \mathrm{M}-\mathrm{H}]^{-}}\end{array}$ & 469 & & $\mathrm{C}_{21} \mathrm{H}_{27} \mathrm{O}_{11} \mathrm{~N}$ & Unidentified \\
\hline 6.46 & $\begin{array}{c}355.1030 \\
{[\mathrm{M}+\mathrm{H}]^{+}} \\
731.1821 \\
{[2 \mathrm{M}+\mathrm{Na}]^{+}}\end{array}$ & $\begin{array}{c}353.0876 \\
{[\mathrm{M}-\mathrm{H}]^{-}} \\
707.1880 \\
{[2 \mathrm{M}-\mathrm{H}]^{-}}\end{array}$ & 354 & -191.0568 & $\mathrm{C}_{16} \mathrm{H}_{18} \mathrm{O}_{9}$ & $\begin{array}{l}\text { Analogue of chlorogenic acid } \\
\text { 4-Caffeoylquinic acid }\end{array}$ \\
\hline 7.58 & 449.1084 & 447.0930 & 448 & 301.0371 & $\mathrm{C}_{21} \mathrm{H}_{20} \mathrm{O}_{11}$ & $\begin{array}{c}\text { Quercetin 3-O- } \alpha \text {-D-rhamnopyranoside } \\
\text { Quercitrin } \\
\text { Kaempferol 3- } O \text {-galactoside } \\
\text { Quercetin 3- } O \text { - } \beta \text {-D-rhamnoside } \\
\text { Astragalin } \\
\text { Orientin }\end{array}$ \\
\hline 7.94 & $\begin{array}{l}463.1241 \\
{[\mathrm{M}+\mathrm{H}]^{+}}\end{array}$ & $\begin{array}{l}461.1087 \\
{[\mathrm{M}-\mathrm{H}]^{-}} \\
923.2253 \\
{[2 \mathrm{M}-\mathrm{H}]^{-}}\end{array}$ & 462 & & $\mathrm{C}_{22} \mathrm{H}_{22} \mathrm{O}_{11}$ & $\begin{array}{l}\text { Isorhamnetin-3-O-rhamnoside } \\
\text { Luteolin 7-O-glucuronide }\end{array}$ \\
\hline 8.34 & - & 359.1504 & 360 & $\begin{array}{c}\text { 313.1465, } 327.1466 \\
\quad 341.1624\end{array}$ & $\mathrm{C}_{20} \mathrm{H}_{24} \mathrm{O}_{6}$ & $\begin{array}{c}\text { (+)-Lariciresinol } \\
\text { 4-O-Methylcedrusin }\end{array}$ \\
\hline
\end{tabular}

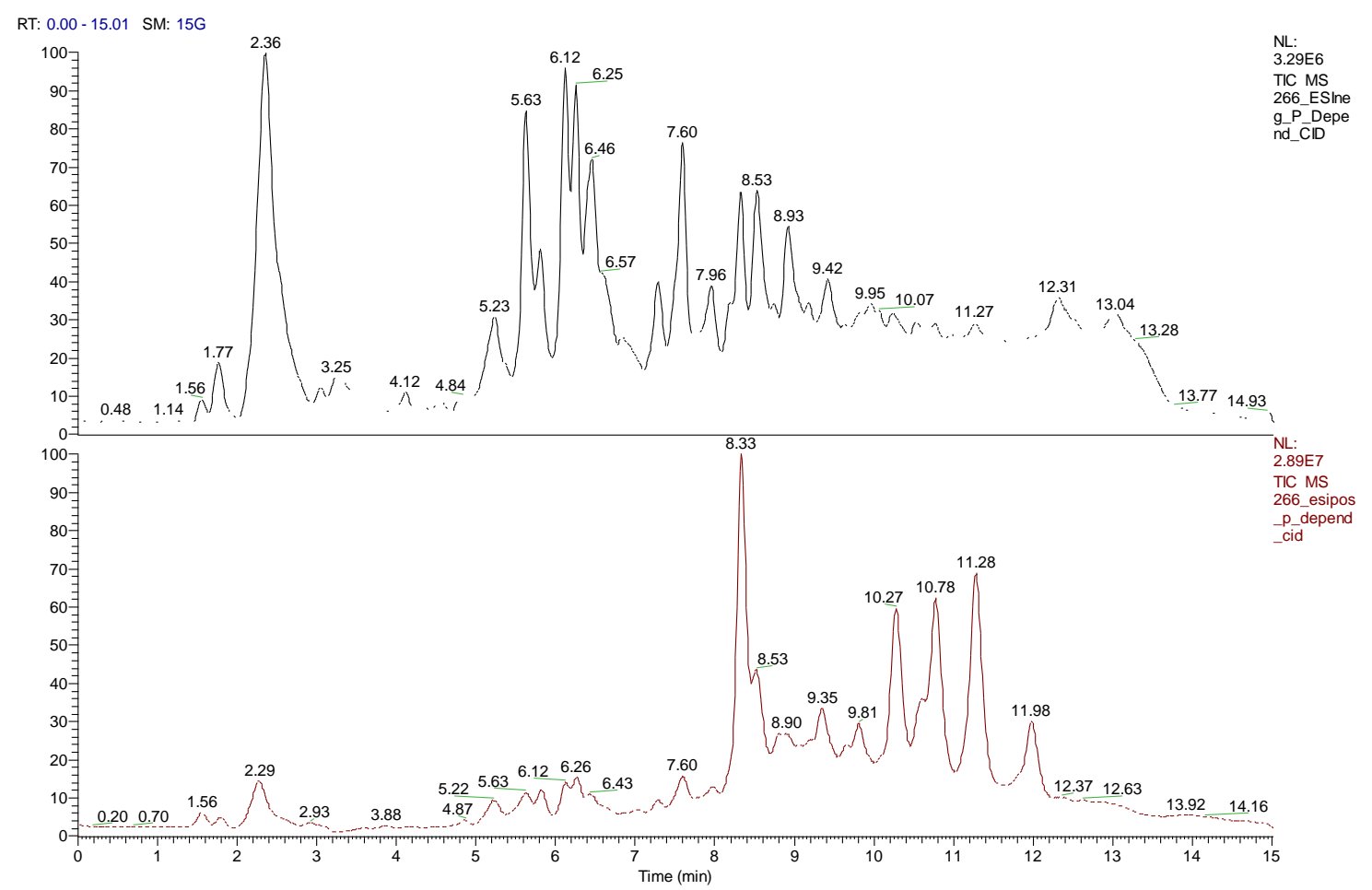

Figure 3. Positive and negative mode TIC spectrum for peumo. TIC of peumo extract is shown in negative and positive modes. 


\section{Discussion}

Both arrayan [Luma apiculata (DC.) Burret] and peumo [Cryptocarya alba (Molina) Looser] plants belong to the trees of Mediterranean ecosystems in Central Chile [3,4]. However, even though both plants are used as food or in traditional medicine, the lack of knowledge about their biological activities and composition still limits their potential applications.

The present study shows the antimicrobial activity of arrayan and peumo extracts, potentially associated with their chemical profiles. The inhibitory effect of arrayan fruits extract against both drug-resistant and drug-sensitive strains of $S$. aureus was overall higher than the peumo fruit extracts (Table 1, Figure 4). Both extracts showed no inhibitory activity against the drug-sensitive strain of P. aeruginosa; however, only the peumo extract showed an effect against the drug-resistant strain of P. aeruginosa. Similar results were also reported by Araya-Contreras et al. [23], who reported significant antimicrobial activity of arrayan leaves extract against Gram-positive S. aureus, but no activity against Gram-negative strains. On the basis of our results, neither peumo nor arrayan extracts can modulate the resistant phenotype of bacteria to chloramphenicol; therefore, their mode of action should be rather direct cytotoxicity than inhibition of mechanisms leading to multidrug-resistance. The antimicrobial activity has been reported for other species belonging to Myrtaceae family of Chile, that is, murta (Ugni molinae Turcz.), as its seed extract showed high antibacterial activity against both Gram-positive (Staphylococcus aureus, Streptococcus pyogenes, and Bacillus cereus) and Gram-negative (Salmonella typhi, Escherichia coli, and Pseudomonas aeruginosa) bacterial strains [21]. Owing to the antimicrobial activity against planktonic cells, we also tested the potential of both extracts to disrupt the mature biofilm. Both extracts disrupted the mature biofilm of $P$. aeruginosa in a concentration-dependent manner; however, none of the tested extracts disrupted the mature biofilm of Gram-positive S. aureus (Table 4).

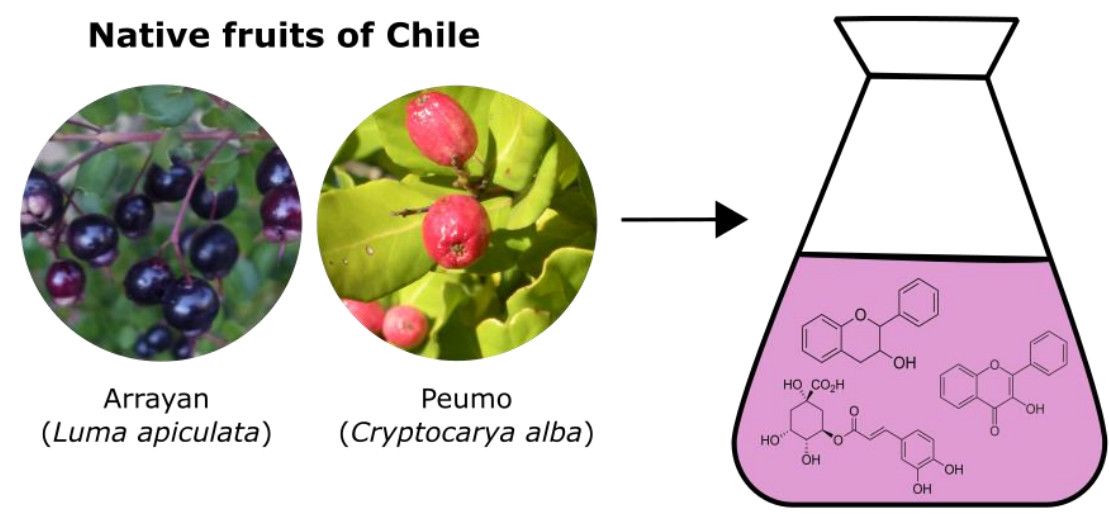

Fruit extracts with antimicrobial molecules

(Catequins, Chlorogenic acid, Myricetin, Quercetin)

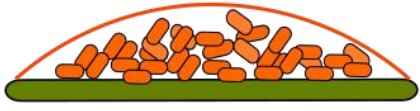

Control bacteria

Biofilm formation

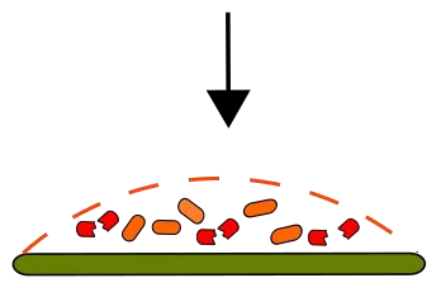

Antimicrobial activity of extracts against $S$. aureus and $\boldsymbol{P}$. aeruginosa

Inhibition of quorum sensing and disruption of preformed biofilm

Figure 4. Graphical abstract of antimicrobial activity of fruit extracts of arrayan and peumo. Both extracts inhibit the growth of $S$. aureus and $P$. aeruginosa pathogenic bacteria potentially associate to its high content of antioxidant molecules. More details are presented in the text. Chemical structures credits [24]. 
Both extracts showed promising activity in inhibition of planktonic and biofilm cells; therefore, their ability to inhibit extracellular communication was also investigated. Firstly, the inhibition of cell adhesion was tested using sensor mutant strains of Vibrio campbellii, and subsequently, the results were confirmed by inhibition of cell adhesion mediated by the cell-to-cell communication (Table 5). The two assays confirmed that the better extract for inhibition of bacterial communication is arrayan extract when applied on bacteria using the AI-2 type of communication. On the basis of our knowledge, this is the first paper reporting on the ability of arrayan fruit to inhibit bacterial extracellular communication altering, potentially through downregulation of the expression of genes related to virulence, motility, sporulation, and biofilm formation [25].

In our study, the U-HPLC/MS analysis showed a significant presence of flavonols, principally quercetin, and its derivate in the extracts of arrayan and peumo fruits (Tables 6 and 7). In arrayan extract, our previous study by High Performance Liquid Chromatography-Diode Array Detector method (HPLC-DAD) showed higher concentration (between 1- and 11-fold differences) of quercetin-3rutinoside compared with anthocyanins [6]. In the same study, we observed the presence of arabinoside and galactoside glycosides coupled to petunidin, peonidin, and malvidin structures. However, we could not identify anthocyanin compounds in the present work. These results could be caused by the previously published fact [10] that secondary metabolites in the aerial biomass strongly variate in medicinal species. The main compounds identified in the peumo extract were chlorogenic acid and its analogs, catechins, and quercetins. Similarly, Simirgiotis et al. [15] reported flavanol derivatives, flavonol aglycones, phenolic acids, and some of their derivatives, flavonoid $O$-glycosides, without anthocyanins reported for the peumo extract. In agreement with our results, Timmermann et al. [26], also reported flavonoids (isorhamnetin, kaempferol, quercetin, and their glycosides) and chlorogenic acid present in leaves extract of peumo. In contrast to the previous report of Castro-Saavedra et al. [27], no alkaloid was detected by U-HPLC/MS. Both fruit extracts showed the presence of quercetins and their derivatives. Quercetin extracted from plants has been reported to inhibit the growth of a broad spectrum of microorganisms, including filamentous fungi and bacteria, with particular effects on E. coli and S. aureus strains [28-30]. It has been suggested that the significant level of phenolics, proanthocyanidins, and tannins, quantified by colorimetric determinations and HPLC-MS/MS, should contribute to the potential antimicrobial activity of the murta seeds extract [21]. Studies have reported that the effect of the polyphenol is related to its ability to interfere with bacteria biofilm (e.g., Enterococcus faecalis) formation at high concentrations [31].

It has also been reported that bioactive fractions rich in tannins, flavonoids, sterols, and glycosides reduced the ampicillin minimum inhibitory concentration against the pathogen [30]. Interestingly, both fruit extracts suppressed the growth of methicillin-resistant $S$. aureus. These results may be owing to the presence of quercetins and their derivatives in both fruit extracts. The quercetin-3-rutinoside has been reported to interact with penicillin-binding protein $2 \mathrm{a}$ ( $\mathrm{PBP} 2 \mathrm{a}$, a cell-wall synthesizing protein), which causes resistivity in methicillin-resistant $S$. aureus (MRSA) against $\beta$-lactam antibiotics [31]. This compound can inhibit PBP2a and thus has the potential to be used in treating MRSA infections [32-34].

Finally, all these results suggest different mechanisms of extracts of arrayan and peumo fruits to inhibit bacterial growth and communication that should be investigated in more detail.

\section{Materials and Methods}

\subsection{Plant Material}

Branches of peumo and arrayan trees, containing leaves and ripe fruits (Figure 1A,B), were collected from Viña del Mar (33 $02^{\prime} 18.58^{\prime \prime}$ S; $71^{\circ} 29^{\prime} 48.04^{\prime \prime}$ W; $77 \mathrm{~m}$ a.s.1., Valparaiso) and Antuco (37 $22^{\prime} 35.01^{\prime \prime}$ S; $71^{\circ} 29^{\prime} 21.20^{\prime \prime}$ W; $850 \mathrm{~m}$ a.s.1., Bio-Bio), respectively. The leaves and fruits were manually separated and washed with a sodium hypochlorite solution $\left(100 \mathrm{mg} \cdot \mathrm{L}^{-1}\right)$ (J.T. Baker ${ }^{\mathrm{TM}}$, Mexico). 


\subsection{Samples Drying and Extracts Preparation}

Fruit samples were freeze-dried, finely ground by hand, and pulverized using a mortar. Three grams of each sample was mixed with $50 \mathrm{~mL}$ of $100 \%$ methanol (J.T. Baker ${ }^{\mathrm{TM}}$, Mexico) for the extraction $[6,35]$. The mixture was shaken (Slow-Speed Orbital Shaker, Cole-Palmer, USA) at $100 \mathrm{rpm}$ and room temperature for $24 \mathrm{~h}$. Then, mixtures were passed by cheesecloth to get rid of big particulates and then through a Whatman No. 1 filter (Whatman International Ltda., Maidstone, UK). Filtered extracts were dried under reduced pressure at $40^{\circ} \mathrm{C}$ using a rotary evaporator (Büchi, Labortechnik AG, Flawil, Switzerland). The extraction yield was calculated as a percentage of dry extract by $3 \mathrm{~g}$ of the initial sample. Crude extracts were reconstituted in methanol to give a concentration of $500 \mathrm{mg} / \mathrm{mL}$, filter-sterilized through a $0.45 \mu \mathrm{m}$ syringe filter (Millipore, Billerica, MA, USA) and stored at $-20{ }^{\circ} \mathrm{C}$.

\subsection{Inhibition of Multidrug-Resistant Bacterial Strains}

The inhibitory activity of both extracts was determined against Gram-positive and Gram-negative bacterial strains. Commercial antibiotics oxacillin and gentamicin (Sigma-Aldrich, USA) were used as a control. Microorganisms were obtained from the Czech Collection of Microorganisms (CCM, Masaryk University, Czech Republic) and the Collection of Laboratory of Medical Microbiology (Czech Laboratory, lnc.): Staphylococcus aureus (control/sensitive strain, ATCC 25923), S. aureus (multidrug-resistant strain, NEM 449), Pseudomonas aeruginosa (control/sensitive strain, ATCC 27853), and P. aeruginosa (multidrug-resistant strain, NEM 986). Staphylococcus aureus NEM 449 was resistant to gentamicin, clindamycin, erythromycin, chloramphenicol, vancomycin, ciprofloxacin, methicillin, penicillin G, cefotaxime, and tetracycline. Pseudomonas aeruginosa NEM 986 was resistant to gentamycin, ciprofloxacin, tetracycline, chloramphenicol, penicillin $\mathrm{G}$, and erythromycin. The resistant or sensitive phenotype was determined by measuring of minimal inhibition concentration (MIC) of each antibiotic by broth dilution method and comparing the MIC value with the clinical breakpoints defined by EUCAST (European Committee on Antimicrobial Susceptibility Testing).

The antibacterial activity of extracts was evaluated by the standard broth-dilution method using 96-well plates and Mueller-Hinton $(\mathrm{MH})$ broth. The overnight microbial culture was diluted to the turbidity equal to $0.5 \mathrm{McF}$ arland. The binary dilutions of the extracts with cell suspension provided the range of tested concentrations from 2 to $1000 \mu \mathrm{g} / \mathrm{mL}$. The control was microbial suspension without the extract. The plates were incubated for $24 \mathrm{~h}$ at $37^{\circ} \mathrm{C}$, and then absorbance $(590 \mathrm{~nm})$ was recorded using the SpectraMax i3x Multi-Mode Detection Platform (Molecular Devices, USA). Each inhibitory activity was measured in four replicates. The sensitization of drug-resistant bacteria was realized according to [36].

\subsection{Inhibition of Biofilm Formation}

The effect of extracts on biofilm formation was tested on S. aureus (ATCC, 25923) and P. aeruginosa (CCM, 3955). The assay was done in 96-well plates. The overnight culture of the tested organism was diluted with brain heart infusion (BHI) broth to obtain the turbidity equal to $0.5 \mathrm{McFarland}$ and split into the plate by the addition of $100 \mu \mathrm{L}$ to each well. The test samples were added to the wells in concentration range of $0.01-5 \mathrm{mg} / \mathrm{mL}$. The plate was incubated for $24 \mathrm{~h}$ at $37^{\circ} \mathrm{C}$. The viability of adherent cells was evaluated immediately by the resazurin assay as follows. The medium was removed, the wells were washed three times by phosphate-buffered saline (PBS), and $100 \mu \mathrm{L}$ of resazurin in PBS (0.03 mg/L) was added. The viability was evaluated by measuring fluorescence (560/590 nm, ex./em.) using the SpectraMax i3x Multi-Mode Detection Platform (Molecular Devices, USA). Each experiment was done in eight repetitions. 


\subsection{Disruption of Mature Biofilm}

We tested the ability of extracts to disrupt mature biofilms formed by monocultures of either S. aureus (ATCC, 25923) or P. aeruginosa (CCM,3955). The assay was done in 96-well plates. The overnight cultures of tested microorganisms were diluted with BHI broth to obtain the turbidity equal to $0.5 \mathrm{McF}$ arland and split to the plates into $100 \mu \mathrm{L}$ aliquots per well. After $24 \mathrm{~h}$ of incubation at $37^{\circ} \mathrm{C}$, the medium was removed, and the wells were washed three times by PBS (pH 7.4). Then, fresh BHI broth was added with extracts. After $24 \mathrm{~h}$ of incubation, the medium was removed, the wells were washed three times by PBS, and $100 \mu \mathrm{L}$ of resazurin in PBS $(0.03 \mathrm{mg} / \mathrm{L})$ was added. The viability was evaluated by measuring fluorescence (560/590 nm, ex./em.) using the SpectraMax i3x Multi-Mode Detection Platform (Molecular Devices, USA). Each experiment was done in 16 repetitions.

\subsection{Inhibition of Quorum Sensing}

For the evaluation of quorum sensing inhibition activity, two commercial (ATCC) strains of Vibrio campbellii were used-BAA1118 and BAA1119. Both strains were cultivated and all experiments were performed in autoinducer bioassay (AB-A) medium composed of $\mathrm{NaCl}(17.5 \mathrm{~g} / \mathrm{L}), \mathrm{MgSO}_{4}(12.3 \mathrm{~g} / \mathrm{L})$, casamino acids $(2 \mathrm{~g} / \mathrm{L}), 10 \mathrm{mM}$ potassium phosphate ( $\mathrm{pH} 7.0), 1 \mathrm{mM}$-arginine, and glycerol (10 mL/L). The overnight culture was diluted with AB-A medium to the density of 0.2 McFarland. This culture was diluted $5000 \times$ with AB-A medium before testing. First, the viability of the Vibrio campbellii was determined to set up the experiment at non-toxic concentrations of both extracts. The twofold dilution of extracts was applied on Vibrio campbellii in 96-well plate, and after $24 \mathrm{~h}$, the cell viability was determined by resazurin assay. The extracts were applied in the non-toxic concentration and further binary diluted with the cell suspension. After that, the luminescence was recorded for $16 \mathrm{~h}$ with a measurement step of 20 min using a microplate reader (SpectraMax i3 Multi-Mode Detection Platform, Molecular Devices, UK) set up at $30{ }^{\circ} \mathrm{C}$; integration time of $10,000 \mathrm{~ms}$; shaking for $60 \mathrm{~s}$ prior each measurement. After the measurements, the data were collected, and the sum of relative luminescence units (RLU) (area under the kinetic curve) was calculated and used for the determination of $\mathrm{IC}_{50}$. Each experiment was done in four repetitions.

\subsection{Data Processing and Statistical Analysis}

The experiments were done with the appropriate number (n) of repetitions, which are shown for each method. The relative activity was evaluated as a percentage according to the formula: $100 \times$ (slope of sample fluorescence-the average slope of PC)/(average slope of NC-the average slope of PC). $\mathrm{IC}_{50}$ values were determined using the software GraphPad Prism 7-nonlinear regression $(\mathrm{Y}=\mathrm{Bottom}$ $+($ Top - Bottom $) /\left(1+10^{\wedge}((\log \mathrm{IC}-\mathrm{X}) \times\right.$ HillSlope $\left.)\right)$. The $\mathrm{IC}_{25}$ was determined using the online tool provided by AAT Bioquest. The data are presented as the averages of the repetitions with the standard error of the mean (SEM). The data were analyzed with a one-way analysis of variance (Tukey multiple comparisons of means, R Project version 4.0., Lucent Technologies, NJ, USA), where the differences were considered statistically significant when $p<0.05$.

\subsection{Ultrahigh-Pressure Liquid Chromatography-Mass Spectrometry (U-HPLC/MS) Analysis}

The U-HPLC/MS analysis was performed by the Laboratory of Mass Spectrometry at the Central Laboratory of UCT. The measurements were performed on a Luna C18 Phenomenex $150 \times 2 \mathrm{~mm}$, $3.1 \mu \mathrm{m}$ column on Thermo LC-MS LTQ-Orbitrap Velos spectrometer in both positive and negative modes. A gradient of $100 \%$ water $(+0.1 \%$ formic acid) to $100 \%$ methanol $(+0.1 \%$ formic acid $)$ was used as the mobile phase over a time of $15 \mathrm{~min}$. The data obtained were analyzed using Xcalibur 2.2. Molecular ion adducts such as $[\mathrm{M}+\mathrm{H}]+,[\mathrm{M}+\mathrm{Na}]+,[2 \mathrm{M}+\mathrm{H}]+,[2 \mathrm{M}+\mathrm{Na}]+,[\mathrm{M}-\mathrm{H}]-,[2 \mathrm{M}-\mathrm{H}]-$, $[2 \mathrm{M}-\mathrm{H}+\mathrm{Na}]-$ were manually identified in order to determine the molecular ion [M]. Once the major molecular ions were identified, a molecular formula (MF) was generated using Xcalibur, and a 
search using the $[\mathrm{M}]$ and MF filter was performed on Scifinder (https://scifinder-n.cas.org/) to identify potential compounds.

\section{Conclusions}

Our findings showed that arrayan and peumo fruits methanol extracts inhibit the growth of both S. aureus and P. aeruginosa pathogenic bacteria. Furthermore, the fruit extracts were effective in controlling the growth of the methicillin-resistant strain of $S$. aureus. The extraction method for obtaining a high content of antioxidant molecules in the extracts is an interesting opportunity for the treatment of tropical diseases. More studies, including the inherent stability of these extracts, are necessary before their future use in medicine.

Author Contributions: Conceptualization, L.F., J.V., and T.R.; methodology, L.F., C.R.F., M.V., R.K., H.L., and K.Ř.; software, R.K., K.Ǩ., and J.V.; validation, K.Ǩ., L.H., and R.K.; formal analysis, J.V. and T.R.; investigation, J.V. and T.R.; resources, J.V. and T.R.; data curation, J.V.; writing—original draft preparation, L.F.; writing-review and editing, L.F., J.V., T.R., M.V., and C.R.F.; visualization, L.F., J.V., K.Ǩ., and R.K; supervision, J.V. and T.R.; project design and administration, J.V. and L.F.; funding acquisition, J.V. and L.F. All authors have read and agreed to the published version of the manuscript.

Funding: This research was funded by CREAS CONICYT-REGIONAL GORE Región de Valparaíso, R17A10001, and by mobility project from the Czech Ministry of Education, Youth, and Sports INTER-COST LTC19007 (COST Action CA17104 STRATAGEM).

Conflicts of Interest: The authors declare no conflict of interest.

\section{References}

1. Schmeda-Hirschmann, G.; Jiménez-Aspee, F.; Theoduloz, C.; Ladio, A. Patagonian berries as native food and medicine. J. Ethnopharmacol. 2019, 214, 111979. [CrossRef] [PubMed]

2. Fuentes, L.; Figueroa, C.R.; Valdenegro, M.; Vinet, R. Patagonian Berries: Healthy Potential and the Path to Becoming Functional Foods. Foods 2019, 8, 289. [CrossRef]

3. Hechenleitner, P.V.; Mf, G.; Thomas, P.; Echeverria, C.; Escobar, B.; Brownless, P.; Martínez, C. Las plantas amenazadas del centro-sur de chile. Distribucón, Conservacion y Propagación; Universidad Austral de Chile y Real Jardın Botá nico de Edimburgo: Valdivia, Chile, 2005; p. 188.

4. Simirgiotis, M.J.; Borquez, J.; Schmeda-Hirschmann, G. Antioxidant capacity, polyphenolic content and tandem hplc-dad-esi/ms profiling of phenolic compounds from the south american berries Luma apiculata and L. Chequen. Food Chem. 2013, 139, 289-299. [CrossRef] [PubMed]

5. Jara-Seguel, P.; Carcamo-Fincheira, P.; Palma-Rojas, C.; von Brand, E. Karyotype morphology of Luma apiculata (dc.) burret (myrtaceae). Gayana Bot. 2013, 70, 395-397. [CrossRef]

6. Fuentes, L.; Valdenegro, M.; Gomez, M.G.; Ayala-Raso, A.; Quiroga, E.; Martinez, J.P.; Vinet, R.; Caballero, E.; Figueroa, C.R. Characterization of fruit development and potential health benefits of arrayan (Luma apiculata), a native berry of south america. Food Chem. 2016, 196, 1239-1247. [CrossRef] [PubMed]

7. Falkenberg, S.S.; Tarnow, I.; Guzman, A.; Molgaard, P.; Simonsen, H.T. Mapuche herbal medicine inhibits blood platelet aggregation. Evidence-Based Complement. Altern. 2012, 2012, 1-9. [CrossRef] [PubMed]

8. Bohm, L.; Arismendi, N.; Ciampi, L. Nematicidal activity of leaves of common shrub and tree species from southern chile against meloidogyne hapla. Cienc. Investig. Agrar. 2009, 36, 249-257. [CrossRef]

9. Pacheco, P.; Sierra, J.; Schmedahirschmann, G.; Potter, C.W.; Jones, B.M.; Moshref, M. Antiviral activity of chilean medicinal plant-extracts. Phytother. Res. 1993, 7, 415-418. [CrossRef]

10. Giordano, A.; Fuentes-Barros, G.; Castro-Saavedra, S.; Gonzalez-Cooper, A.; Suarez-Rozas, C.; Salas-Norambuena, J.; Acevedo-Fuentes, W.; Leyton, F.; Tirapegui, C.; Echeverria, J.; et al. Variation of secondary metabolites in the aerial biomass of cryptocarya alba. Nat. Prod. Commun. 2019, 14, 11. [CrossRef]

11. Bravo, J.; Carbonell, V.; Sepulveda, B.; Delporte, C.; Valdovinos, C.E.; Martin-Hernandez, R.; Higes, M. Antifungal activity of the essential oil obtained from cryptocarya alba against infection in honey bees by nosema ceranae. J. Invertebr. Pathol. 2017, 149, 141-147. [CrossRef] 
12. Pinto, J.J.; Silva, G.; Figueroa, I.; Tapia, M.; Urbina, A.; Rodriguez, J.C.; Lagunes, A. Insecticidal activity of powder and essential oil of cryptocarya alba (molina) looser against sitophilus zeamais motschulsky. Chil. J. Agric. Res. 2016, 76, 48-54. [CrossRef]

13. Di Cosmo, D.; Santander, R.; Urzua, A.; Palacios, S.M.; Rossi, Y. Insecticidal effect of cryptocarya alba essential oil on the housefly, musca domestica L. Bol. Latinoam. Caribe Plantas Med. 2015, 14, 113-117.

14. Carmona, E.R.; Reyes-Diaz, M.; Parodi, J.; Inostroza-Blancheteau, C. Antimutagenic evaluation of traditional medicinal plants from south america peumus boldus and cryptocarya alba using drosophila melanogaster. J. Toxicol. Environ. Health A 2017, 80, 208-217. [CrossRef] [PubMed]

15. Simirgiotis, M.J. Antioxidant capacity and hplc-dad-ms profiling of chilean peumo (Cryptocarya alba) fruits and comparison with german peumo (Crataegus monogyna) from southern chile. Molecules 2013, 18, 2061-2080. [CrossRef] [PubMed]

16. Schmeda-Hirschmann, G.; Razmilic, I.; Gutierrez, M.I.; Loyola, J.I. Proximate composition and biological activity of food plants gathered by chilean amerindians. Econ. Bot. 1999, 53, 177-187. [CrossRef]

17. Schmeda-Hirschmann, G.; Astudillo, L.; Bastida, J.; Codina, C.; De Arias, A.R.; Ferreira, M.E.; Inchaustti, A.; Yaluff, G. Cryptofolione derivatives from cryptocarya alba fruits. J. Pharm. Pharmacol. 2001, 53, 563-567. [CrossRef]

18. Bansal, S.; Choudhary, S.; Sharma, M.; Kumar, S.; Lohan, S.; Bhardwaj, V.; Syan, N.; Jyoti, S. Tea: A native source of antimicrobial agents. Food Res. Int. 2013, 53, 568-584. [CrossRef]

19. Shen, X.; Sun, X.; Xie, Q.; Liu, H.; Zhao, Y.; Pan, Y.; Hwang, C.-A.; Wu, V.C.H. Antimicrobial effect of blueberry (Vaccinium corymbosum L.) extracts against the growth of listeria monocytogenes and salmonella enteritidis. Food Control. 2014, 35, 159-165. [CrossRef]

20. Sáez, F.; Narváez, G.F.; Morales, M.; Bello-Toledo, H.; Balbontin, C.; Figueroa, C. Physiochemical and antibacterial characterization of fruits of citronella mucronata (cardiopteridaceae), pitavia punctata (rutaceae) and beilschmiedia berteroana (lauraceae), three endemic and threatened chilean trees. Fruits 2017, 72, 87-96. [CrossRef]

21. Cabrera, G.; Wilkens, M.; Giordano, A.; Bernardo, Y.; Delgado, N. Chemical composition and antibacterial activity of red murta (Ugni molinae Turcz.) seeds: An undervalued chilean resource. J. Food Meas. Charact. 2020, 14, 1810-1821. [CrossRef]

22. Mason, T.L. Inactivation of red beet beta glucan synthase by native and oxidized phenolic compounds. Phytochemistry 1987, 26, 2197-2202. [CrossRef]

23. Araya-Contreras, T.; Veas, R.; Escobar, C.A.; Machuca, P.; Bittner, M. Antibacterial effect of Luma apiculata (dc.) burret extracts in clinically important bacteria. Int. J. Microbiol. 2019, 2019, 1-7. [CrossRef]

24. Wikimedia Commons. Available online: https://commons.wikimedia.org/wiki/Main_Page (accessed on 22 July 2020).

25. Miller, M.B.; Bassler, B.L. Quorum sensing in bacteria. Annu. Rev. Microbiol. 2001, 55, 165-199. [CrossRef] [PubMed]

26. Timmermann, B.N.; Valcic, S.; Liu, Y.L.; Montenegro, G. Flavonols from cryptocarya alba. Z. Naturforsch. C 1995, 50, 898-899. [CrossRef]

27. Castro-Saavedra, S.; Fuentes-Barros, G.; Tirapegui, C.; Acevedo-Fuentes, W.; Cassels, B.K.; Barriga, A.; Vilches-Herrera, M. Phytochemical analysis of alkaloids from the chilean endemic tree Cryptocarya alba. J. Chil. Chem. Soc. 2016, 61, 3076-3080. [CrossRef]

28. Cushnie, T.P.; Lamb, A.J. Antimicrobial activity of flavonoids. Int. J. Antimicrob. Agents 2005, 26, $343-356$. [CrossRef]

29. Sato, Y.; Suzaki, S.; Nishikawa, T.; Kihara, M.; Shibata, H.; Higuti, T. Phytochemical flavones isolated from scutellaria barbata and antibacterial activity against methicillin-resistant Staphylococcus aureus. J. Ethnopharmacol. 2000, 72, 483-488. [CrossRef]

30. Rauha, J.P.; Remes, S.; Heinonen, M.; Hopia, A.; Kahkonen, M.; Kujala, T.; Pihlaja, K.; Vuorela, H.; Vuorela, P. Antimicrobial effects of finnish plant extracts containing flavonoids and other phenolic compounds. Int. J. Food Microbiol. 2000, 56, 3-12. [CrossRef]

31. Fiamegos, Y.C.; Kastritis, P.L.; Exarchou, V.; Han, H.; Bonvin, A.M.J.J.; Vervoort, J.; Lewis, K.; Hamblin, M.R.; Tegos, G.P. Antimicrobial and efflux pump inhibitory activity of caffeoylquinic acids from artemisia absinthium against gram-positive pathogenic bacteria. PLoS ONE 2011, 6, e18127. [CrossRef] 
32. Santiago, C.; Pang, E.L.; Lim, K.H.; Loh, H.S.; Ting, K.N. Inhibition of penicillin-binding protein 2a (pbp2a) in methicillin resistant staphylococcus aureus (mrsa) by combination of ampicillin and a bioactive fraction from duabanga grandiflora. BMC Complement. Altern. Med. 2015, 15, 178. [CrossRef]

33. Rani, N.; Vijayakumar, S.; PTV, L.; Arunachalam, A. Allosteric site-mediated active site inhibition of pbp2a using quercetin 3-o-rutinoside and its combination. J. Biomol. Struct. Dyn. 2016, 34, 1778-1796. [CrossRef]

34. Rani, N.; Vijayakumar, S.; Thanga Velan, L.P.; Arunachalam, A. Quercetin 3-o-rutinoside mediated inhibition of pbp2a: Computational and experimental evidence to its anti-mrsa activity. Mol. Biosyst. 2014, 10, 3229-3237. [CrossRef] [PubMed]

35. Karaman, İ.; Sahin, F.; Güllüce, M.; Ogutcu, H.; Sengül, M.; Adiguzel, A. Antimicrobial activity of aqueous and methanol extracts of juniperus L. J. Ethnopharmacol. 2003, 85, 231-235. [CrossRef]

36. Viktorova, J.; Dobiasova, S.; Rehorova, K.; Biedermann, D.; Kanova, K.; Seborova, K.; Vaclavikova, R.; Valentova, K.; Ruml, T.; Kren, V.; et al. Antioxidant, anti-inflammatory, and multidrug resistance modulation activity of silychristin derivatives. Antioxidants 2019, 8, 303. [CrossRef] [PubMed]

(C) 2020 by the authors. Licensee MDPI, Basel, Switzerland. This article is an open access article distributed under the terms and conditions of the Creative Commons Attribution (CC BY) license (http://creativecommons.org/licenses/by/4.0/). 